\title{
Performance of agricultural tractor consuming diesel and biodiesel derived from babassu (Orbinya martiana)
}

\author{
Thyago Augusto Medeiros Lira*, Ariston Pinto Santos, Thaisa Calvo Fugineri Moreti, Afonso Lopes, Melina \\ Cais Jejcic de Oliveira, Murilo Coelho Theodoro Neves, Priscila Sawasaki Iamaguti, Leomar Paulo de Lima, \\ Gilberto Hirotsugu Azevedo Koike, Rogerio de Abreu Silva
}

Universidade Estadual Paulista - UNESP - Campus Jaboticabal/SP - Brazil

*Corresponding author: thyagolira@hotmail.com

\begin{abstract}
Biodiesel is an alternative fuel to diesel engines. This study aimed to evaluate fuel consumption and smoke density of agricultural tractors fueled by biodiesel, diesel, and biodiesel/diesel mixtures in a tilled field. Treatments consisted of distilled methyl ester (biodiesel) of babassu (Orbinya martiana) and seven combinations of it with two standard diesel fuels (B S1800 and B S50). The blending ratios were $0,5,15,25,50$, and $100 \%$ biodiesel in diesel oil (B0, B5, B15, B25, B50, and B100, respectively). Regarding the results for hourly volumetric consumption, no difference was found between B0 and B100 when using B S1800, whereas an $8 \%$ increase was observed when using the S50. The weighted hourly consumption increased by 11.29 and $16.9 \%$ from B0 to B100 using B S1800 and B S50, respectively. Similarly, the specific fuel consumption increased by $11.1 \%$ and $14.3 \%$ from B0 to B100 using B S1800 and B S50, respectively. Yet, when comparing B0 and B S1800, the smoke density reduction was $68.6 \%$ and between B S50 and B100 was $58.0 \%$. Our findings show that babassu biodiesel is a suitable substitute for diesel oil, without causing any damage to the tractor's engine.
\end{abstract}

Keywords: Biofuel; Bioenergy; Farm tractor tests; Specific fuel consumption.

Abbreviations: $\mathrm{CO}_{2}$ Carbon dioxide; S1800_diesel with 1800 ppm of sulfur; S50_diesel with 50 ppm of sulfur; BIOEM_Laboratory of Biofuel and Machinery Test; UNESP_São Paulo State University; LADETEL_Laboratory for Clean Technology; USP_São Paulo University; B0_0\% Biodiesel; B5_5\% Biodiesel; B15_15\% Biodiesel; B25_25\% Biodiesel; B50_50\% Biodiesel; B75_75\% Biodiesel; B100_100\% Biodiesel; HVC_hourly volumetric consumption; Sv_Fuel supply volume; Rv_Fuel return volume; $t$ _Travel speed; WHC_Weight hourly consumption; SFC_Specific fuel consumption; Dp_Drawbar power; SD _Smoke density; FWA_Front-wheel assist; FAPESP_Fundação de Amparo à Pesquisa do Estado de São Paulo (Foundation for Research Support of the State of São Paulo); CNPq_Conselho Nacional de Desenvolvimento Cientifico e Tecnológico (Brazilian Council for Scientific and Technological Development); CAPES_Coordenação de Aperfeiçoamento de Pessoal de Nível Superior (Coordination for the Improvement of Higher Level Personnel); COOPERCITRUS_Cooperativa de Produtores Rurais (Farmers' Cooperative for Citrus Production).

\section{Introduction}

Diesel is the most commonly used fuel for internal combustion engines of high power output (Zhu et al., 2010). One of its main problems stems from the high amount of sulfur reacting with oxygen in combustion producing sulfur dioxide, which is one of the major air pollutants worldwide (Muzic et al., 2009).

Biodiesel use has substantially increased, mainly for its lack of sulfur and renewable resource origin, contributing to the carbon cycle (Silitonga et al., 2011; Mofijur et al., 2012; Zhou et al., 2012). While $\mathrm{CO}_{2}$ from biofuel combustion is recycled by the same plants originating the oil, that from fossil fuel burning is released into the atmosphere, wherein it remains for millions of years until it is absorbed by plants (Zhou et al., 2012).

According to the annual report by the British Petroleum Company (BP, 2014), renewable energy use increased by $81 \%$ between 2000 and 2013. Biofuels stood out among the most used resources, increasing by $622 \%$ throughout the same years. The same report forecasted a $40 \%$ increase in general energy demand until the year 2035, being most striking for those from renewable sources.

Recently, some studies have assessed the performance of agricultural tractors fueled with biodiesel from pongamia, castor beans, soybeans, oil palm, tucumã, murumuru, and buriti (Faria et al., 2010; Nietiedt et al., 2011), analyzing the smoke density of the exhausts (Lima et al., 2012, 2013; Neves et al., 2013; lamaguti, 2014). These tests have enabled the use of biofuels in diesel engines with no damages, besides reducing smoke density dramatically. Among the vegetal resources used for biofuel production, Brazilian oleaginous palms such as babassu (Orbignya martiana) have stood out. This plant has been grown throughout the northeastern, northern, and mid-western Brazil, as well as in Mexico and Bolivia (Silva et al., 2014). 
According to research published in 2013 by the Brazilian Institute of Geography and Statistics (IBGE), Brazil is the largest babassu producer globally. The whole country produces 97,820 tons of almonds per year, within which the state of Maranhão accounts for $97.45 \%$.

Sousa et al. (2013) verified the percentage of fatty acids in babassu oil by gas chromatography. These researchers observed high concentrations of short-chain saturated fatty acids, which make such oil an excellent choice for biodiesel production. However, saturated fatty acids tend to crystallize at low temperatures, limiting biofuel use in colder regions. Souza et al. (2009) evaluated the flames from the burning of vegetal oil biodiesel using a calorimetry oven and images from an infrared pyrometer. These authors concluded that the flame temperatures of common diesel fuel are higher than are those of biodiesel, which explains the higher heat transfer rates of diesel.

lamaguti et al. (2016) assessed engine performance and smoke density of agricultural tractors fueled with a combination of buriti biodiesel and common diesel at several different proportions; when comparing B0 and B100 biodiesel proportions, they observed a $5.41 \%$ increase in specific fuel consumption. However, when substituting diesel (B S1800 and B S50) for biodiesel at B100, the smoke density decreased by 33.33 and $28.90 \%$, respectively.

The hypothesis of this study was the following: the use of babassu biodiesel in diesel engines will cause no damages, being a potential substitute for petroleum diesel. Therefore, the objectives were to evaluate operational performance and smoke density of agricultural tractor engines fueled with two types of diesel (B S1800 and B S50) containing different blending proportions of babassu biodiesel (B0, B5, B15, B25, $\mathrm{B} 50, \mathrm{~B} 75$, and $\mathrm{B} 100)$.

\section{Results and Discussion}

\section{Tractor performance (essay I)}

\section{Fuel Consumption}

Table 1 presents the interactions between diesel types and biodiesel proportions for the assessed variables. Hence, the mentioned variables were analyzed and discussed separately through statistical breakdown (Tables 2, 3 and 4).

Table 2 shows that no hourly volumetric consumption differences were found for any biodiesel proportion added to the B S1800 diesel. In contrast, this variable increased by $7.4 \%$ when using B S50 from B0 to B100. These results differ from those found by Lima et al. (2012), who evaluated a Valtra tractor (model BM110) equipped with a turbo engine fueled with interior diesel fuel B S1800 and mixtures of palm oil and tucumã biodiesel. These authors observed a $23.0 \%$ increase in volumetric consumption, by raising biodiesel proportion from $\mathrm{B} 0$ to $\mathrm{B} 100$. According to the same authors, this is due to the lower calorific value of biodiesel compared to diesel, which in turn requires more fuel for the same performance. Such explanations also coincide with those of Souza et al. (2009), who had assessed the flames from burning of residual vegetal oil and biodiesel. These contradictions can be justified by the variation in calorific values of biofuels from different origins. Methyl babassu biodiesel has flash point and viscosity (112 $\circ \mathrm{C}$ and $4.0 \mathrm{~mm}^{2} \mathrm{~s}$ 1) (Soares et al., 2011) closer to those of diesel ( $38 \stackrel{\circ}{\circ}$ and 2.0 to $5.0 \mathrm{~mm}^{2} \mathrm{~s}^{-1}$ ANP no $\left.50 / 2013\right)$ as compared to the ones of palm biodiesel ( $180{ }^{\circ} \mathrm{C}$ and $4.7 \mathrm{~mm}^{2} \mathrm{~s}^{-1}$ ) (Santos et al., 2010). The results in Table 2 denote reductions of 7.43, 11.4, 10.2, $6.1,7.4$, and $4.0 \%$ in hourly volumetric consumption when using B S50 at proportions of B0, B5, B15, B25, B50, and B75, respectively. These results are in accordance with those of Tabile et al. (2009), who compared B S1800 and B S500 diesel in combination with different proportions of castor biodiesel in a Valtra tractor (model BM100) turbo engine. These authors concluded that such consumption drops using B S500 were achieved by its higher quality compared to B S1800. Similar results, but with an $11.27 \%$ increase in volumetric consumption, were found by Faria et al. (2010); they concluded that increasing biodiesel proportions reduces atomization and jet range from injection nozzles and, consequently, higher consumption and emission. Nietiedt et al. (2011) also found similar results (i.e., 10.9\% increase in specific consumption) for mixtures of mineral diesel with methyl soy biodiesel from B5 to B100.

Specifying the fuel consumption in terms of volume is important as it facilitates expense management by farmers, and is easily obtained and analyzed.

In general, with increased proportions of biodiesel, fuel consumption increased by $10 \%$ for B S1800 (B0-B100) and $14.4 \%$ for B S50 (B25-B100). Such difference might have been because of the higher density and reduced fuel value of such blends. According to Tabile et al. (2009), an increase in weighted consumption using biodiesel proportions from B0 to B100 occurs because of lower density and calorific value of diesel in comparison to biodiesel.

Table 3 shows that, when comparing B S1800 and B S50, as biodiesel proportions increased in $\mathrm{BO}, \mathrm{B} 5$, and $\mathrm{B} 15$, the weighted hourly consumption decreased by $4.8,8.7$, and $7.2 \%$, respectively. However, lamaguti (2014) found no consumption differences between B S1800 and B S50 for buriti biodiesel.

Regarding the specific fuel consumption, Table 4 discloses that the only significant increase for B S1800 was $11.1 \%$ between B0 and B100. Conversely, B S50 presented significant increases starting from $B 25$, being of 3.8, 2.3, 8.9, and $14.4 \%$ for $\mathrm{B} 25, \mathrm{~B} 50, \mathrm{~B} 75$, and $\mathrm{B} 100$, respectively, as compared with $\mathrm{B} 0$. Our results are according to those of Neves et al. (2013), who combined B S1800 diesel with varied proportions of murumuru biodiesel; they observed a $10.6 \%$ increase in specific consumption between BO and B100. Likewise, lamaguti (2014) found a $14.8 \%$ increase in specific consumption for blends of B S1800 diesel with buriti biodiesel. According to Murugesan et al. (2009) and Tabile et al. (2009), such disparities are due to the higher density and lower calorific value of biodiesel compared to diesel.

Faria et al. (2010) also observed an increase in specific fuel consumption and inferred that increasing rates of biodiesel in diesel fuel blends reduce automation capability and jet radial penetration and, hence, higher consumption and emission. Likewise, Nietiedt et al. (2011) reported a $10.9 \%$ increase in specific consumption by increasing the proportion of soybean methyl biodiesel from B5 to B100, in blends with mineral diesel. In this evaluation, the authors tested a tractor with diesel direct-injection Perkins engine, at a nominal power of $45 \mathrm{~kW}$ and $1900 \mathrm{rpm}$, using a dynamometer bench.

Table 4 shows a comparison between B S1800 and B S50, in which the latter showed no effect on specific consumption. 
Table 1. Summary of variance analysis and mean test for the variables: hourly volumetric consumption (HVC), weighted hourly consumption (WHC) and specific fuel consumption (SFC).

\begin{tabular}{|c|c|c|c|}
\hline Factors & HVC & WHC & SFC \\
\hline \multicolumn{4}{|c|}{ Type of Diesel (TD) } \\
\hline B S1800 & 14.8 & 12.7 & 298.1 \\
\hline B S50 & 13.8 & 12.3 & 286.1 \\
\hline \multicolumn{4}{|c|}{ Proportion of Biodiesel $\left(B_{n}\right)$} \\
\hline BO & 14.2 & 12.1 & 280.7 \\
\hline B5 & 14.1 & 12.0 & 282.4 \\
\hline B15 & 13.9 & 12.0 & 279.1 \\
\hline B25 & 14.3 & 12.4 & 290.2 \\
\hline B50 & 14.1 & 12.4 & 288.7 \\
\hline B75 & 14.5 & 12.9 & 302.1 \\
\hline B100 & 14.8 & 13.4 & 321.6 \\
\hline \multicolumn{4}{|l|}{ TEST $\mathrm{F}$} \\
\hline TD & $124.8697^{* *}$ & $29.1455 * *$ & $27.8181^{* *}$ \\
\hline$B_{n}$ & $5.9265^{* *}$ & $36.6290 * *$ & $25.1316 * *$ \\
\hline$T D \times B_{n}$ & $5.8088^{* *}$ & $4.7344 * *$ & $3.7154^{* *}$ \\
\hline C.V. (\%) & 1.9 & 2.1 & 2.5 \\
\hline Average & 14.3 & 12.5 & 292.1 \\
\hline
\end{tabular}

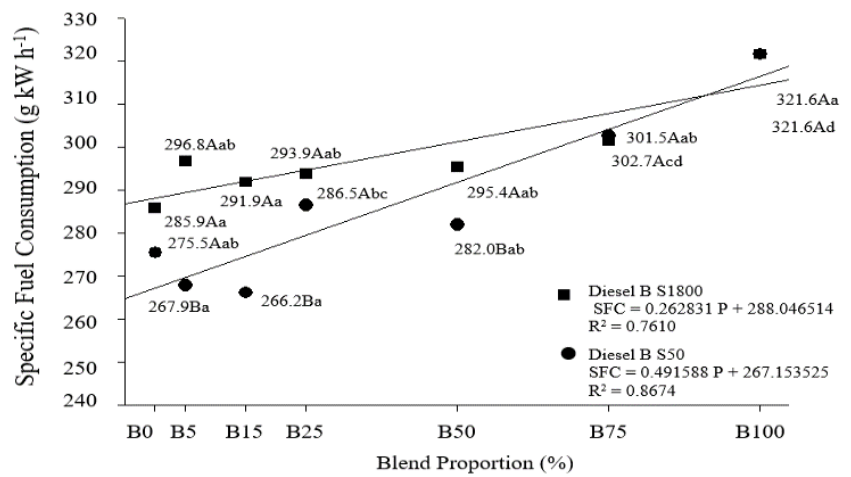

Fig 1. Regression model fitting showing specific fuel consumption (SFC) as a function of diesel types and blends with different proportions of methyl babassu biodiesel.

Table 2. Summary of the results of interactions between types of diesel and proportions of methyl babassu biodiesel for hourly volumetric consumption (HVC).

\begin{tabular}{lccccccc}
\hline Type of & \multicolumn{9}{c}{ Proportion of Biodiesel } \\
\cline { 2 - 8 } Diesel & B0 & B5 & B15 & B25 & B50 & B75 & B100 \\
\hline B S1800 & $14.8 \mathrm{Aa}$ & $14.9 \mathrm{Aa}$ & $14.7 \mathrm{Aa}$ & $14.7 \mathrm{Aa}$ & $14.7 \mathrm{Aa}$ & $14.8 \mathrm{Aa}$ & $14.8 \mathrm{Aa}$ \\
B S50 & $13.7 \mathrm{Bab}$ & $13.2 \mathrm{Ba}$ & $13.2 \mathrm{Ba}$ & $13.8 \mathrm{Bab}$ & $13.6 \mathrm{Bab}$ & $14.2 \mathrm{Bbc}$ & $14.8 \mathrm{Ac}$ \\
\hline
\end{tabular}

Means followed by the same capital letter in the column and lower-case letter in the line do not vary between them, according to the Tukey's test at $5 \%$ probability.

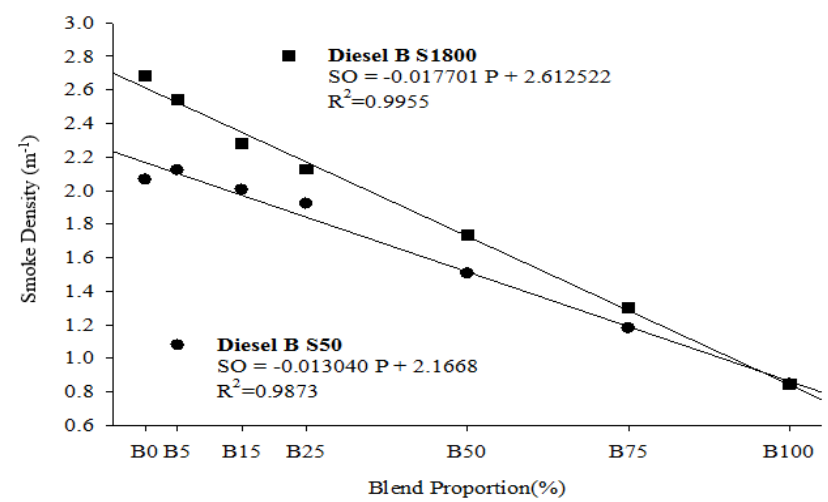

Fig 2. Regression model fitting explaining smoke density (SD) as a function of diesel types and blends with different proportions of methyl babassu biodiesel. 
Table 3. Summary of the results of interactions between types of diesel and proportions of methyl babassu biodiesel for weighted hourly consumption (WHC).

\begin{tabular}{|c|c|c|c|c|c|c|c|}
\hline \multirow{2}{*}{$\begin{array}{l}\text { Type of } \\
\text { diesel }\end{array}$} & \multicolumn{7}{|c|}{ Proportion of Biodiesel } \\
\hline & $\mathrm{BO}$ & B5 & B15 & B25 & $\mathrm{B} 50$ & B75 & B100 \\
\hline B S1800 & 12.4Aa & 12.6Aab & 12.4Aab & 12.5Aab & 12.6Aab & 12.8Aab & $13.8 \mathrm{Bb}$ \\
\hline B S50 & $11.8 \mathrm{Bab}$ & $11.5 \mathrm{Ba}$ & 11.5Ba & $12.2 \mathrm{Ab}$ & $12.2 \mathrm{Ab}$ & 13.0Ac & 13.8Ad \\
\hline
\end{tabular}

Means followed by the same capital letter in the column and lower-case letter in the line do not vary between them, according to the Tukey's test at $5 \%$ probability.

Table 4. Statistical breakdown of the interactions between types of diesel and proportions of methyl babassu biodiesel for specific fuel consumption (SFC).

\begin{tabular}{|c|c|c|c|c|c|c|c|}
\hline \multirow{2}{*}{$\begin{array}{l}\text { Type of } \\
\text { Diesel }\end{array}$} & \multicolumn{7}{|c|}{ Proportion of Biodiesel } \\
\hline & BO & B5 & B15 & B25 & $\mathrm{B} 50$ & B75 & B100 \\
\hline B S1800 & 285.9Aa & 296.8Aab & 291.9Aa & 293.9Aab & 295.4Aab & 301.5Aab & $321.6 \mathrm{Ab}$ \\
\hline B S50 & 275.5Aab & 267.9Ba & $266.2 \mathrm{Ba}$ & $286.5 A b c$ & 282.0Bab & 302.7Acd & $321.6 \mathrm{Ad}$ \\
\hline
\end{tabular}

Means followed by the same capital letter in the column and lower-case letter in the line do not vary between them, according to the Tukey's test at $5 \%$ probability.

Table 5. Variance analysis and mean test for smoke density (SD).

\begin{tabular}{lc}
\hline FACTORS & DENSITY \\
\cline { 2 - 2 } TYPE OF DIESEL (TD) & $\mathrm{m}^{-1}$ \\
B S1800 & 1.92 \\
B S50 & 1.65 \\
\hline PROPORTIONS OF BIODIESEL (Bn) & \\
B0 & 2.34 \\
B5 & 2.33 \\
B15 & 2.14 \\
B25 & 2.02 \\
B50 & 1.61 \\
B75 & 1.21 \\
B100 & 0.84 \\
\hline TESTE F & \\
TD & $262.1696 * *$ \\
Bn & $702.9601 * *$ \\
TD $x$ Bn & $26.3929 * *$ \\
\hline C.V.\% & 5.9 \\
\hline Average & 1.78 \\
\hline D1): $*$ sigin (P<0.05); & \\
\hline
\end{tabular}

** significant $(\mathrm{P}<0.01) ;{ }^{*}$ : significant $(\mathrm{P}<0.05)$; C.V.: coefficient of variation.

Table 6. Summary of the results of interactions between types of diesel and proportions of methyl babassu biodiesel for smoke density (SD).

\begin{tabular}{|c|c|c|c|c|c|c|c|}
\hline \multirow{2}{*}{ Type of diesel } & \multicolumn{7}{|c|}{ Proportion of Biodiesel } \\
\hline & B0 & B5 & B15 & B25 & B50 & B75 & B100 \\
\hline B S1800 & $2.68 \mathrm{Aa}$ & $2.54 \mathrm{Ab}$ & $2.27 \mathrm{Ac}$ & $2.12 \mathrm{Ad}$ & 1.73Ae & $1.25 \mathrm{Af}$ & $0.84 \mathrm{Ag}$ \\
\hline B S50 & 2.00Bab & $2.12 \mathrm{Ba}$ & 2.00Bab & $1.92 \mathrm{Bb}$ & $1.50 \mathrm{Bc}$ & $1.18 \mathrm{Ad}$ & $0.84 \mathrm{Ae}$ \\
\hline
\end{tabular}

Means followed by the same capital letter in the column and lower-case letter in the line do not vary between them, according to the Tukey's test at $5 \%$ probability.

Again, in comparing both diesel types, the biodiesel proportions of $\mathrm{B} 5, \mathrm{~B} 15$, and $\mathrm{B} 50$ caused a reduction in specific consumption by $9.7,8.8$, and $4.5 \%$, respectively. For Lôbo et al. (2009) and Dabdoub et al. (2009), this discrepancy may be related to the fuel quality.

Previous studies have shown broad-scale increases in specific consumption by changing diesel for biodiesel. Tabile et al. (2009) evaluated blends of the interior $\left(2,000 \mathrm{mg} \mathrm{kg}^{-1}\right.$ sulfur) and metropolitan (500 $\mathrm{mg} \mathrm{kg}^{-1}$ sulfur) diesel types with seven proportions of castor ethyl biodiesel and noted a $38.3 \%$ increase in specific consumption from B0 to B100. Equally, Oliveira (2013) studied castor oil biodiesel and observed a $31.3 \%$ increase in specific consumption within the same ratios. Yet, Neves et al. (2013) observed a slighter increase (15.85\%) using soy biodiesel in an agricultural tractor equipped with an intercooler system.
As seen in Figure 1, specific consumption behavior as a function of mixture proportions was fit to a linear regression model. Through this graphic illustration, it is also apparent reductions of $9.7,8.8$, and $4.5 \%$ in specific fuel consumption when blending respectively $\mathrm{B} 5, \mathrm{~B} 15$, and $\mathrm{B} 50$ with $\mathrm{S} 50$ as compared to the same proportions of B S1800 diesel.

As when comparing B S1800 with B S50, the B S50 diesel presented no reductions in specific fuel consumption. Conversely, following the same analogy for B5, B15, and B50, reductions of $9.7,8.8$, and $4.5 \%$ were observed, respectively.

The importance of expressing fuel use in the terms of specific consumption lies in satisfying needs of the scientific community and engine designers since this variable includes fuel volume and density, as well as available power at the drawbar. 


\section{Smoke Density (Essay II)}

Table 5 displays significant interaction between diesel types and biodiesel proportions for smoke density. This is why this variable was analyzed separately and discussed in detail (Table 6).

We observed significant reductions in smoke density as biodiesel ratios increased (Table 6 ). When confronting $B$ S1800 and B S50, reductions were of $68.6 \%$ and $58.0 \%$ from $\mathrm{B} 0$ to B100, respectively. This behavior was already expected given the free oxygen in biodiesel molecule, which increases combustion efficiency in diesel cycle engines. Lima et al. (2012) observed a similar behavior while testing a Valtra tractor (model BM110) equipped with a turbo engine fueled with interior diesel (B S1800) mixed with amounts of biodiesel. Moreover, these authors reported that palm and tucumã biodiesel reduced smoke density by $36.25 \%$ and $60.0 \%$, respectively. Analyzing B S1800 and B S500 diesel, De Oliveira et al. (2016) observed similar reductions, 37\% and $60 \%$, when using soy and murumuru biodiesels, respectively. Once again, Lira et al. (2016) reported the same trend testing an agricultural tractor, equipped with a turbo engine and intercooler, fueled with two diesel types (B S1800 and B S10) blended with proportions of babassu biodiesel (B50 and B100). The latter authors observed larger smoke density reductions during tractor use using B100, being of $49.77 \%$ and $47.64 \%$ for B S1800 and B S10, respectively.

For pure diesel, smoke density was reduced by $25.4 \%$ using B S50 instead of B S1800. Proceeding likewise for the biodiesel proportions, the reductions were of 16.5, 11.9, 9.4, and $13.3 \%$ for $\mathrm{B} 5, \mathrm{~B} 15, \mathrm{~B} 25$, and $\mathrm{B} 50$ compared to $\mathrm{B} 0$, respectively. These reductions encourage biodiesel use. As previously stated, this biofuel has free oxygen in its molecule, which reduces the formation of fuel-rich zones inside the combustion chamber; hence enhancing performance and efficiency during diffusion combustion, and reducing particulate matter emissions (Sahoo et al., 2009; Chauhan et al., 2012). Particulate emissions from biodiesel combustion in diesel engines are lower than those of diesel fuel (Janaun and Ellis, 2010; Ong et al., 2011; Xue et al., 2011; Bora and Baruah, 2012).

To visualize smoke density from both types of diesel and blends with babassu biodiesel at varying proportions, the data fit a linear regression model were plotted in Figure 2.

\section{Materials and Methods}

\section{Area and soil description}

Experiments were conducted at Faculdade de Ciências Agrárias e Veterinárias, UNESP Universidade Estadual Paulista, Campus Jaboticabal, Departamento de Engenharia Rural, Biocombustível e Ensaio de Máquinas - BIOEM. The area is located at coordinates $21{ }^{\circ} 15^{\prime}$ south and $48018^{\prime}$ east, 570 meters above sea level. The annual averages of temperature, rainfall, and relative humidity are respectively 22.2 o $\mathrm{C}, 1,425 \mathrm{~mm}$, and $71 \%$, and an atmospheric pressure of $94.3 \mathrm{kPa}$ (UNESP, 2011). The regional climate is classified by Kottek et al. (2006) as Cwa, defined as subtropical with dry winter, in transition to Aw, which is tropical-wet with defined rain period in summer. The soil is classified as Eutrustox with a gently rolling topography and an average slope of 3\%, according to Brazilian Soil Classification System (Andreoli and Centurion, 1999). Soil water content was measured by a gravimetric method on the experiment day, being of 11.2 and $13.4 \%$ for $0-15$ and $15-30 \mathrm{~cm}$ depths, respectively. Particle size analysis $(\%)(0-20 \mathrm{~cm})$ revealed it is a clayey soil with layers of clay, silt, and fine and coarse sand representing $51,29,10$, and $10 \%$, respectively.

\section{Diesel}

The two standard diesel fuels, B S1800 and B S50, used in the experiments were acquired from a regular gas station and classified according to ANP (National Agency of Petroleum) Resolution no 65, of December 9, 2011 (ANP 2012).

\section{Biodiesel}

The biodiesel (B100) was obtained by transesterification using methanol, being provided by the Laboratório de Desenvolvimento de Tecnologias Limpas- LADETEL from Universidade de São Paulo - USP.

\section{Fuel blends}

Seven blends of biodiesel and diesel were prepared for each standard diesel. The biodiesel content in diesel was B0, B5, B15, B25, B50, B75, and B100, standing for 0, 5, 15, 25, 50, 75 , and $100 \%(v / v)$. The mixing of biodiesel and diesel was performed before each test.

\section{Tractor}

The tractor tested in this study consisted of an AGCO-Valtra, model BM 125i, $4 \times 2$ with a front-wheel assist (FWA), 7,000 $\mathrm{kg}$ distributed between the front $(40 \%)$ and rear axle $(60 \%)$ and with tires 14.9-26 inches on the front axle and 23.1-30 inches on the rear axle. It had a four-stroke and four-cylinder diesel engine (AGCO POWER 420DS), with a maximum power of $91.9 \mathrm{~kW}$ at 2,300 rpm (ISO 1585), equipped with a turbocharger and intercooler. The power-to-weight ratio was $76 \mathrm{~kg} / \mathrm{kW}$.

This study was divided into two parts: Essay 1 - tests were conducted under field conditions to evaluate tractor's performance; and Essay 2 - a static phase performed to measure smoke density from the engine. The experiments were categorized into two topics as follows: Essay I - Tractor Performance and Essay II - Engine Smoke density.

\section{Experiment procedures}

\section{Tractor performance (Essay I)}

The performance of the tractor was evaluated through measurement of drawbar power, forward speed, specific weight, and volumetric fuel consumption during chiseling. To define the maximum drawbar load, a pilot test was conducted with a chisel plow (model AST/MATIC 7Marchesan). It had a total mass of $1,400 \mathrm{~kg}$ and five $45-\mathrm{cm}$ long shanks, with an 8-cm reversible point working at a 30 $\mathrm{cm}$ depth (shank-distance/depth ratio: 1.5). Each shank was equipped with coulter blades, an automatic spring- 
cushioned system (trip/reset mechanism), and rolling harrow. The measured travel reduction (slippage) was $10 \%$, consistent with ASAE standards (2006); the drawbar power to pull the chisel plow implement during the operation was $25 \mathrm{kN}$.

As soil resistance varies widely during operation, a braking tractor was coupled to the test tractor by means of a steel wire, forming a train-like configuration. Then, a preliminary test was carried out to calibrate the braking tractor for a drawbar power of about $25 \mathrm{kN}$. While calibrating, the tractor was shut off and engaged, with a combination of fourth gear, $L$ range (shift position), and front-wheel drive (FWD) activated. This second tractor was a Valmet, model 118-4, $4 \times 2 \mathrm{FWA}$, and 7,310 kg distributed between the front (40\%) and rear axle $(60 \%)$, with tires $14.9-28$ inches on the front axle and 23.1-30 inches on the rear axle. It is equipped with a four-stroke and six-cylinder diesel engine (MWM D229/6), with a maximum power of $82.43 \mathrm{~kW}$ at $2,400 \mathrm{rpm}$. According to Lopes (2006), the second tractor was connected to the test tractor by a stainless-steel cable. Once its function was to provide an optimal drawbar pull load $(25 \mathrm{kN})$ for the test tractor with little working speed variation, the second tractor was off and engaged.

The tractor started to move from a line $15 \mathrm{~cm}$ outside the plots, so that stabilized determinations could be reached. Every time the tractor's reference point (center of the rear wheel) crossed the first landmark, data began to be recorded, ending with the crossing of the second landmark. Fuel consumption was measured by the difference in volume between the fuel supplied to the injection pump and fuel returned to the tank. Fuel temperature was used to correct changes in density. Two sets of data acquisition were installed; one at the injection pump (supply line) and another at the tank (return line). Each set contained a flow meter (Flowmate Oval, model LSF 41 ) with a precision of $1 \%$ at a nominal flow $100 \mathrm{~L} \mathrm{~h}^{-1}$; and a platinum resistance thermometer PT 100 (from 100 ohms at 0 ㅇ to 138.4 ohms

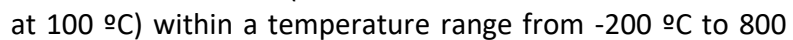
oC. The fuel consumption estimator used here was the prototype built by and described in Lopes et al. (2003). This system has three auxiliary fuel tanks, which allows the testing of various types and mixtures of fuels without any contamination.

Fuel consumption was calculated using Equations 1, 2, and 3. First, we estimated the hourly consumption based on the amount of fuel used and travel time across each plot as defined in Equation (1):

$$
H V C=\left(\frac{S v-R v}{t}\right) * 3.6
$$

where,

$\mathrm{HVC}=$ hourly volumetric consumption $\left(\mathrm{L} \mathrm{h}^{-1}\right)$;

Sv = supply fuel volume $(\mathrm{mL})$;

$\mathrm{Rv}=$ return fuel volume $(\mathrm{mL})$;

$\mathrm{t}=$ travel time (s); and,

$3.6=$ conversion factor.

Then, we calculated the weighted hourly consumption using the fuel density and the difference between the amount of fuel supplied and returned while testing, as in Equation (2):

$W H C=\left(\frac{S v * S d-R v * R d}{t}\right) * 0.0036$

Where,

WHC = weight hourly consumption $\left(\mathrm{kg} \mathrm{h}^{-1}\right)$;

Sv = supply fuel volume $(\mathrm{mL})$;
$\mathrm{Sd}=$ supply fuel density $\left(\mathrm{kg} \mathrm{m}^{-3}\right)$;

$\mathrm{Rv}=$ return fuel volume $(\mathrm{mL})$;

$\mathrm{Rd}=$ return fuel density $\left(\mathrm{kg} \mathrm{m}^{-3}\right)$;

$\mathrm{t}=$ travel time $(\mathrm{s})$; and,

$0.0036=$ conversion factor.

Lastly, we computed the specific fuel consumption, expressed in mass per power required at drawbar, according to Equation (3):

$S f c=\left(\frac{W H C}{D p}\right) * 1000$

where,

$\mathrm{SFC}=$ specific fuel consumption $\left(\mathrm{g} \mathrm{kW} \mathrm{h}^{-1}\right)$;

WHC = Weight hourly consumption $\left(\mathrm{kg} \mathrm{h}^{-1}\right)$;

$\mathrm{Dp}=$ Drawbar power $(\mathrm{kW})$, and

$1000=$ conversion factor.

Running speed was recorded using a radar system (Dick John brand, model RVS II), which has $97 \%$ accuracy within a speed range from 3.2 to $70.8 \mathrm{~km} \mathrm{~h}^{-1}$. Drawbar pull was measured by a load cell (M. Shimitsu, model TF 400). Wheel slippage was determined by sensors (S\&E I, model GIDP-60-U12V) installed in each wheel, providing a number of individual pulses per wheel. This sensor main function is determining the wheel angular displacement based on its rotation, where one revolution corresponds 60 electrical pulses.

An auxiliary battery was used to power all transducers and sensors. All data on fuel consumption, fuel temperature, drawbar power, wheel rotation, and travel speed were monitored and stored in a data acquisition system (Campbell Scientific Model CR23X micrologger, Campbell Scientific Inc., Logan, Utah, USA), which is programmed to collect data at 1 $\mathrm{Hz}$ frequency and interfaced by a serial port (RS232).

\section{Smoke density (Essay - II)}

The smoke density was quantified using the Snap Acceleration Smoke Test Procedure. In this method, the throttle was moved towards to its maximum and kept until the maximum governed speed is reached, remaining for further 1 to $4 \mathrm{~s}$. Later, the throttle was released and the engine is allowed to return to the low-idle speed. After reaching its low-idle speed, the engine idled for at least 5 to $45 \mathrm{~s}$ before initiating the next snap-acceleration test cycle. The smoke density (k), also known as "Light Absorption Coefficient", is expressed per meter $\left(\mathrm{m}^{-1}\right)$. It is a measure of the number of smoke particles per unit volume of gas. It works based on size distribution, light absorption, and optical scattering properties of smoke particles (SAE, 1996).

The measures were made using a partial-flow opacimeter TM 133, attached to a serial TM 616 (both are produced by Tecnomotor). This system collected data and then transmitted them to a computer with IGOR version 2.0 software.

Before each test, unburnt fuel was collected from tanks, filters, and pipes to prevent contamination to subsequent tests. After changing the fuel, the engine remained in operation for ten minutes before the beginning of each test, to be consistent.

\section{Statistical analysis}

The experiment was performed in a completely randomized $7 \times 2$ factorial design, with three replications. The factors 
were seven blends of diesel and biodiesel B0, B5, B15, B25, $B 50, B 75$, and $B 100$, where $B$ indicates the percentage of biodiesel added to diesel, and two types of diesel (B S1800 and B S50). For tractor performance test, each plot had $40 \mathrm{~m}$ long and further $15 \mathrm{~m}$ for tractor maneuvering and stabilization.

Data were submitted to variance analysis and means were compared by the Tukey's test. A variance analysis (F-test) was used to select the equation model with the most significant exponent.

\section{Conclusion}

The specific consumption of babassu biodiesel increased by 11.1 and $14.3 \%$ as compared to B S1800 and B S50 diesel, respectively. In contrast, it showed smoke density reductions of 68.2 and $58 \%$ against S1800 and B S50, respectively.

Blends of babassu biodiesel and B S50 diesel reached lower specific consumption and greater smoke density reductions if compared to mixtures with B S1800 diesel.

Biodiesel from babassu palm oil can be used to replace petroleum diesel. This alternative fuel can enhance employability and income in the primary sector, in addition to developing a self-sustaining economy, essential for the country's autonomy.

\section{Acknowledgements}

The authors thank the FAPESP (process number 01/099728), CNPq, CAPES, and the associated laboratory of government agencies BIOEM/IPBEN/UNESP for the financial support to purchase tractor instrumentation, and to the companies Coopercitrus and Valtra for providing the testing tractors.

\section{References}

Abnt. Associação Brasileira de Normas Técnicas (2001) NBR 13037: Veículos rodoviários automotores - gás de escapamento emitido por motor em aceleração livre Determinação da opacidade. Available: <http://www.abnt.org.br/catalogo>. Access: January 15, 2017.

Andreoli I, Centurion JF (1999) Detailed survey of the faculty of agricultural sciences and veterinary Jaboticabal. In: Proceedings Brazilian Soil Science Congress (T025-3 CDROM):1-32.

Anp. Agência Nacional do Petróleo, Gás Natural e Biocombustíveis (2012) Resolução ANP no 46, de 20 de dezembro de 2012. Available: <http://www.anp.gov.br>. Access: January 15, 2017.

Asae (2006) EP 496.2 DEC98. Agricultural Machinery Management. In: ASAE Standards: standards engineering practices data. St. Joseph: Am Soc of Agric Eng. 1-6.

Bora DK, Baruah DC (2012) Assessment of tree seed oil biodiesel: A comparative review based on biodiesel of a locally available tree seed. Renew Sust Energ Rev. 16(3):1616-1629.

BP. BP Group Companies (2014) BP Statistical Review of World Energy. 63rd ed. 45 p. Available: <http://www.bp.com/content/dam/bp/pdf/Energyeconomics/statistical-review-2014/BP-statistical-reviewof-world-energy-2014-full-report.pdf>. Access: February 1,
2017.

Chauhan BS, Kumar N, Cho HM (2012) A study on the performance and emission of a diesel engine fueled with Jatropha biodiesel oil and its blends. Energy 37(1):616622.

Dabdoub MJ, Bronzel JL, Rampin MA (2009) Biodiesel: visão crítica do status atual e perspectivas na academia e na indústria. Quim Nova 32(3):776-792.

De Oliveira MCJ, Lopes A, De Lima LP, Neves MCT, lamaguti PS, Lira TAM, Moreti TCF, Koike GHA, Santos AP, Silva RA (2016) Effect of type of fuel and speed of engine on the performance of agricultural tractor. Afr J Agric Res. 11(40):4048-4054.

Faria MDC, Pinto RRC, Valle MLM (2010) Efeito do biodiesel na atomização do combustível em motores diesel de injeção direta. R Quím Industr. 727:22-27.

lamaguti OS (2014) Biodiesel de buriti em trator: desempenho em função do tipo de diesel e da proporção de mistura na operação de preparo do solo. 61f. Dissertação (Mestrado em Agronomia) - Universidade Estadual Paulista, Faculdade de Ciências Agrárias e Veterinárias de Jaboticabal, Jaboticabal.

lamaguti PS, Lopes A, De Oliveira MCJ, Neves MCT, Lira TAM, Moreti TCF, Koike GHA (2016) Operational performance of tractor running with diesel and biodiesel from buriti oil (Mauritia flexuosa). Aust J Crop Sci. 10(3):336-341.

Ibge. Instituto Brasileiro de Geografia e Estatística. Anuário Estatístico do Brasil. Rio de Janeiro, 2013. v. 73. Available: <http://www.ibge.gov.br>. Access: April 1, 2017.

Janaun J, Ellis N (2010) Perspectives on biodiesel as a sustainable fuel. Renew Sust Energ Rev. 14(4):1312-1320.

Kottek M, Grieser J, Beck C, Rudolf B, Rubel F (2006) World map of the Köppen-Geiger climate classification updated. Meteorol Z. 15:259-263.

Lima LP, Lopes A, Oliveira MCJ, Neves MCT, lamaguti PS (2013) Biodiesel in an agricultural tractor: operational behavior as a function of the type and proportions blended in diesel fuel. Eng Agric. 21(5): 447-455.

Lima LP, Lopes A, Oliveira MCJ, Neves MCT, Koike GHA (2012) Comparativo entre biodiesel de dendê e tucumã no desempenho operacional de trator agrícola. Eng Agric. 20(3):234-243.

Lira TAM, Moreti TCF, Lopes A, Santos AP, De Oliveira MC, Neves MCT, lamaguti PS, De Lima LP, Koike GHA, Silva RA (2016) Smoke opacity of ethyl biodiesel from babassu and two types of diesel at different daytimes. Afr J Agric Res. 11(40):4055-4061.

Lôbo IP, Ferreira SLC, Cruz RS (2009) Biodiesel: parâmetros de qualidade e métodos analíticos. Quim Nova 32(6):1596-1608.

Lopes A, Furlani CEA, Silva RP (2003) Desempenho de um protótipo para medição de combustível em tratores. RBIAgro. 5(1):24-31.

Mofijur M, Masjuki HH, Kalam MA, Shahabuddin M (2012) Experimental study of additive added palm biodiesel in a compression ignition engine. EEST PART A. 30(SI-1)737748.

Muzic M, Sertic-Bionda K, Gomzi Z, Podolski S, Telen S (2010) Study of diesel fuel desulfurization by adsorption. Chem Eng Res Des. 88(4):487-495.

Neves MCT, Lopes A, Lima LP, Oliveira, MCJ, Koike GHA (2013) Performance of an agricultural tractor in function of biodiesel type (soybean $\mathrm{x}$ murumuru) in soil preparation. 
Eng Agric. 21(4): 351-360.

Nietiedt GH, Schlosser JF, Ribas RL, Frantz UG, Russini A (2011) Desempenho de motor de injeção direta sob misturas de biodiesel metílico de soja. Cienc Rural 41(7):1177-1182.

Oliveira LE, Giordani DS, Paiva EM, Castro HF, Silva MLCP (2013) Kinetic and thermodynamic parameters of volatilization of biodiesel from babassu, palm oil and mineral diesel by thermogravimetric analysis (TG). J Therm Anal Calorim. 111(1):155-160.

Ong HC, Mahlia TMI, Masjuki HH, Norhasyima RS (2011) Comparison of palm oil, Jatropha curcas and Calophyllum inophyllum for biodiesel: A review. Renew Sust Energ Rev. 15(8): 3501-3515.

Sahoo PK, Das LM, Babu MKG, Arora P, Singh VP, Kumar NR, Varyani TS (2009) Comparative evaluation of performance and emission characteristics of Jatropha, Karanja and Polanga based biodiesel as fuel in a tractor engine. Fuel 88(9):1698-1707.

Santos AGD, Caldeira VPS, Farias MF, Silva EFB, Araújo AS, Fernandes Júnior VJ, Souza L (2010) Síntese, caracterização e estudo cinético do óleo de dendê e seu biodiesel. In: 4 은 Congresso Brasileiro de Mamona e 10 Simpósio Internacional de Oleaginosas Energéticas. João Pessoa, June 2010.

Silitonga AS, Atabani AE, Mahlia TMI, Masjuki HH, Badruddin IA, Mekhilef S (2011) A review on prospect of Jatropha curcas for biodiesel in Indonesia. Renew Sust Energ Rev. 15(8):3733-3756.

Silva MCD, Da Silva LM, Brandão KS, Souza AG, Cardoso LP, Santos AO (2014) Low temperature properties of winterized methyl babassu biodiesel. J Therm Anal
Calorim. 115(1):635-640.

Soares IP, Rezende TF, Pereira RCC, Santos CG, Fortes ICP (2011) Determination of biodiesel adulteration with raw vegetal oil from ATR-FTIR data using chemometric tools. J Braz Chem Soc. 22(7):1229-1235.

Sousa LC, Rocha ED, Rocha CP (2013) Análises de óleos vegetais e óleo residual bruto por cromatografia gasosa visando à produção do biodiesel. Conexão Ci. 8(2):85-91.

Souza GR, Santos AM, Ferreira SL, Martins KCR, Módolo DL (2009) Evaluation of the performance of biodiesel from waste vegetal oil in a flame tube furnace. Appl Therm Eng. 29(11-12):2562-2566.

Tabile RA, Lopes A, Dabdoub MJ, Camara FT, Furlani CEA, Silva RP (2009) Biodiesel de mamona no diesel interior e metropolitano em trator agrícola. Eng Agr-Jaboticabal 29(3):412-423.

Tecnomotor. Tecnomotor Eletrônica Do Brasil (2014) Opacímetro TM 133: manual de instruções. Cod: 50087. 04th edn. Tecnomotor, São Carlos. 8.

Unesp (2011) Dados normais. Departamento de Ciências Exatas: Estação meteorológica.

Xue J, Grift TE, Hansen AC (2011) Effect of biodiesel on engine performances and emissions. Renew Sust Energ Rev. 15(2):1098-1116.

Zhou W, Li Y, Zhang Y, Zhao Z (2012) Energy efficiency evaluation of lipid production by oleaginous yeast Rhodosporidium toruloides. J Therm Anal Calorim. 108(1):119-126.

Zhu L, Zhang W, Liu W, Huang Z (2010) Experimental study on particulate and NOx emission of a diesel engine fueled with ultralow sulfur diesel, RME-diesel blends and PMEdiesel blends. Sci. Total Environ. 408(5):1050-1058. 